\title{
Impact of crayfish densities on wet seeded rice and the inefficiency of a non-ionic surfactant as an ecotechnological solution
}

\author{
P.M. Anastácio ${ }^{\mathrm{a}, *}$, A.F. Frias ${ }^{\mathrm{b}}$, J.C. Marques ${ }^{\mathrm{b}}$ \\ a IMAR-Department of Ecology, University of Évora, Apartado 94, 7001 Évora codex, Portugal \\ ${ }^{\mathrm{b}}$ IMAR-Department of Zoology, University of Coimbra, 3000 Coimbra, Portugal
}

Received 27 March 1998; received in revised form 5 January 1999; accepted 20 January 1999

\begin{abstract}
In order to compare the effects of crayfish (Procambarus clarkii) on rice production, with and without the use of a non-ionic surfactant (Genapol OX-80) at a concentration of $0.005 \%, 12$ enclosures at $1 \mathrm{~m}^{2}$ containment area were built in each of two experimental fields. Crayfish densities used in the experiment were: $0,1,3$, and 5 adult crayfish per $\mathrm{m}^{-2}$. In each field, at harvest time, five randomly chosen areas of $1 \mathrm{~m}^{-2}$ were also sampled for rice, infestants and sediment characteristics. Additionally, the number of filled grains per panicle, the percentage of empty grains and the 100 grains weight were determined. One of the experimental fields was used as the treatment (field T) and another one as the control (field C), and no statistically significant differences ( $p>0.05$, Mann-Whitney $\mathrm{U}$ test) were found between them. No perceptible reduction in crayfish damaging effects was observed after the use of the surfactant in field $\mathrm{T}$. Results of an ANOVA performed on the effects of crayfish density on rice production at each field were statistically significant $(p<0.05)$. There was a total destruction $(100 \%)$ of rice in the enclosures with densities of 3 and 5 crayfish $\mathrm{m}^{-2}$. Some infestant macrophytes survived at 3 crayfish $\mathrm{m}^{-2}$ in both fields and at 5 crayfish $\mathrm{m}^{-2}$ in field C. At lower densities $\left(1\right.$ crayfish $\mathrm{m}^{-2}$ ) the average decrease in grain production attributable to crayfish was $41.61 \%$. Results provided data to calibrate a management model and suggested that the surfactant is not effective in field conditions. (C) 2000 Elsevier Science B.V. All rights reserved.
\end{abstract}

Keywords: Procambarus clarkii; Oryza sativa; Integrated production; Crawfish; Pests; Pesticides

\section{Introduction}

Crayfish damage to rice crops has been well documented (Chang and Lange, 1967; Grigarick

\footnotetext{
* Corresponding author. Tel.: + 351-66-745385; fax: + 35166-29498.

E-mail address: anast@evunix.uevora.pt (P.M. Anastácio)
}

and Way, 1982; Sommer and Goldman, 1983; Sommer, 1984) and like in other places, crayfish (Procambarus clarkii) introduction in Portugal became a problem for rice farmers (Adão and Marques, 1993; Anastácio and Marques, 1995; Anastácio et al., 1995). To prevent damage to rice production, farmers have repeatedly tried to eradicate crayfish populations by means of xenobiotic 
chemicals. Such methods proved to be ineffective and had a devastating impact on useful species (Velez, 1980; Roqueplo and Hureaux, 1989). In fact, once introduced into favorable habitats, $P$. clarkii is rather difficult to eliminate (Holdich, 1988).

In this context, the use of a non-ionic surfactant was proposed as a means of reducing destructive crayfish activity in rice fields, by lowering crayfish metabolic rate (Anastácio et al., 1995; Fonseca et al., 1996). The active ingredient (100\%) of Genapol OX-80, produced by Hoechst Portuguesa is a mixture of polyglycol ethers of fatty alcohols- $\mathrm{CH}_{3}-\left(\mathrm{CH}_{2}\right)_{12-15}-\mathrm{O}\left(\mathrm{CH}_{2} \mathrm{CH}_{2} \mathrm{O}\right) \mathrm{H}$ and has a half life time of 2 weeks (data from Hoechst). Genapol has several advantages (Jørgensen et al., 1997), namely: (a) crayfish would not be killed and could be harvested at a later stage; (b) bioaccumulation is an important environmental concern and is expected to be significantly lower when using Genapol in comparison with the use of xenobiotics such as dimethoate or parathion; (c) the toxicity of Genapol is relatively low (Cabral et al., 1996), especially in comparison with pesticides commonly used in rice fields in order to control crayfish populations (Chang and Lange, 1967; Baker, 1975; Brown and Avault, 1975). It was assumed that rice production would not be affected by the surfactant.

The planning of practical measures to control the size of crayfish populations or for double cropping crayfish and rice, demands substantial knowledge of their biology and ecology, namely with regard to crayfish-rice interaction in new habitats. Actually, most decisions concerning the control of crayfish population densities are taken based on mere intuition. A study attempting to quantify crayfish damages to rice was performed in Californian rice fields by Grigarick and Way (1982), but in general, although negative effects are known to exist, the causes are not always clear to farmers (Savary, 1993) or even scientists. Damage by crayfish has been attributed to excavatory behavior (Chang and Lange, 1967; Sommer and Goldman, 1983; Sommer, 1984; Huner, 1988; Arrignon et al., 1990; Adão and Marques, 1993; Caño and Ocete, 1994) resulting in destruction of levees and loss of water from the fields. At least one work (Correia, 1993) suggests that crayfish damage to rice occurs by interference with the establishment of germinated rice seeds, and another mentions effects on the early stages of rice growth (Grigarick and Way, 1982).

A more recent work (Anastácio and Marques, 1996) confirmed that crayfish may have a serious negative impact on rice in the first days after sowing. In addition, the same authors determined values for rice seedling destruction and suggested that turbidity caused by crayfish might be one of the causes of that destruction. Nevertheless, final rice production might not be reduced as intensely as the reduction in seedling survival would suggest. In fact, rice plants may suffer considerable tillering (i.e. formation of new branches at the base of the plants) from 25 to 40 days after sowing (Tinarelli, 1989 in Bellido, 1991) and the seed production may be improved when competition is reduced. Macrophytes are potential competitors with rice plants and their susceptibility or resistance to crayfish presence could influence rice production.

The use of crayfish as a resource may help to control population size, with a simultaneous profit of food value. Correct planning and optimization of efforts involved in rice or ricecrayfish farming can be achieved by means of ecological models (Anastácio et al., 1995) and this process is called ecological engineering (Mitsch and Jørgensen, 1989). Environmental ecological models are a powerful tool for quantitative and qualitative management of natural resources (Jørgensen, 1989), therefore, the development of a model of simultaneous crayfish and rice production was considered suitable. Some of the crucial parameters for a model of crayfish and/or rice production includes the amount of damage to the rice crop as a function of crayfish densities. The present work is an attempt to document the effects of crayfish on rice production, with and without the use of a surfactant (Genapol OX-80). Additionally, results will be used to calibrate a management model still in development (Anastácio et al., 1995, 1999) for crayfish and rice production. 


\section{Methods}

\subsection{Study site}

The Lower Mondego River valley is located in the central region of Portugal $\left(40^{\circ} 10^{\prime} \mathrm{N}, 8^{\circ} 41^{\prime} \mathrm{W}\right)$. Average (30 years) air temperature is $15.5^{\circ} \mathrm{C}$ and annual precipitation ranges from 800 to $1190 \mathrm{~mm}$ (Ferreira, 1991). The valley consists of approximately 15000 ha and the main agricultural crop is rice, which occupies about $60 \%$ of the valley. Field experiments were conducted in 1996 in the 'Seminário' farm, near the Pranto river, in two 0.7 ha rice fields. These fields were not infested by crayfish (i.e. density 0 crayfish $\mathrm{m}^{-2}$ ) as was confirmed by trapping and visual checking for crayfish presence.

\subsection{Field experiment}

A total of 12 enclosures of $1 \mathrm{~m}^{2}$ containment area were constructed in each of two experimental fields after soil preparation in the beginning of March. All the nets (5 mm mesh) surrounding the enclosures were buried $50 \mathrm{~cm}$ deep, and the top was covered with plastic. The experimental design was 'systematic' for each field (see Hulbert, 1984 or Krebs, 1989). Enclosures were placed in each field on a straight line and spaced $4 \mathrm{~m}$ from each other. Crayfish sequential densities (per enclosure) in each line were $0,1,3,5,0,1,3,5,0,1,3,5$. Therefore, the effect of any possible gradients in the field was overcome. The densities were chosen based on a previous work in which densities of 0 , 1,5 and 10 crayfish $\mathrm{m}^{-2}$ were tested. These showed no survival of rice plants at 5 crayfish $\mathrm{m}^{-2}$.

Crayfish used to stock the enclosures were collected from the adjacent irrigation channels, 2 days prior to rice seeding. Average crayfish post orbital carapace length (POCL) was $2.96 \mathrm{~cm}$, ranging from 2.5 to $3.5 \mathrm{~cm}$ (see Anastácio and Marques, 1995 for conversion equations). Dead crayfish were removed and replaced within the first 3 days. A total of $18 \mathrm{~g}$ (ca. 450 seeds) of pre soaked rice variety Ariete were sown on the 2 May in each enclosure at the same time as rice was sown in the rest of the fields. Standard rice farming practices were undertaken, such as preplant application of fertilizer (8-16-16, N-P-K) and Ordram herbicide. No insecticides were used in the experimental fields.

To test the effects of Genapol OX-80, one of the fields was used as treatment (field $\mathrm{T}$ ) and the other as the control (field C). It was not possible to replicate field treatments due to the large scale of the experiment. Genapol OX-80 was applied in the treatment field $(\mathrm{T})$ on the 1 May, to attain a final concentration of $0.005 \%$. For the assessment of Genapol OX-80 effects on rice production and to compare rice production inside and outside the enclosures, five randomly chosen areas of $1 \mathrm{~m}^{-2}$ were sampled in each field on the 23 September, just before harvest. Vegetation inside and outside the enclosures was cut at the base on the same day and infestant macrophytes were separated from rice plants. Rice grains were threshed by hand and the dry weight of all the vegetative components was determined. Sediment samples were collected $5 \mathrm{~cm}$ deep in the soil to determine organic content. The dry weights of all samples was determined after drying at $80^{\circ} \mathrm{C}$ for $48 \mathrm{~h}$. Ash free dry weight (AFDW) was calculated after burning in a muffle oven at $450^{\circ} \mathrm{C}$ for $7 \mathrm{~h}$. The same procedures were followed for the samples from the enclosures.

Additional standard rice production parameters were determined in the field samples in order to provide more data for comparison of the control and treatment fields, and to provide a better view of the rice production in the area. These included: number of filled grains per panicle, percentage of empty grains and the adjusted 100 grains weight (14\% moisture). Gomez (1972) described the procedures for estimating these production parameters in rice planted in hills, but instead of hills, we used groups of nearby plants (visually identifiable). Three samples of four groups of nearby rice plants were collected in each field and the total number of panicles were counted in all samples from each field. In each group of plants, the central panicle (tallest) was separated from the others. The filled and unfilled grains from the center panicles were separated by hand and counted after threshing. Filled grains were also weighed. The last operations were performed after 
separating filled and unfilled threshed grains from the rest of the panicles. Unfilled grains were counted and filled grains were weighed.

\section{Results}

\subsection{Surfactant effects on rice production-comparison of samples obtained outside the enclosures}

The control and treatment fields showed no statistically significant differences $(p>0.05$, Mann-Whitney U test). Parameters analyzed in-

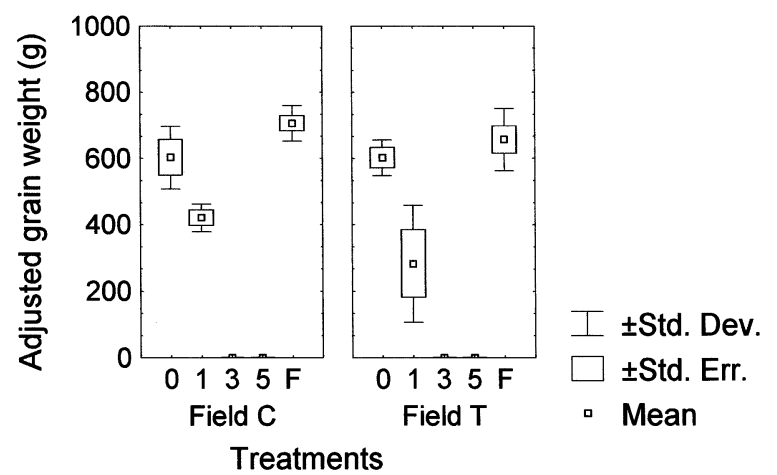

Fig. 1. Adjusted grain weight (14\% moisture) production per $\mathrm{m}^{2}$ at several crayfish (Procambarus clarkii) densities $(0,1,3$, 5 ) in enclosures and from field samples outside the enclosures (F). Field $\mathrm{C}$ is the control field and $\mathrm{T}$ is the treatment field.
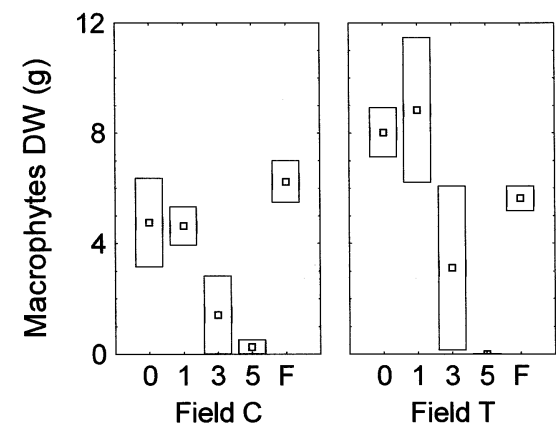

\pm Std. Err.

Treatments

Fig. 2. Aerial biomass of macrophytes (dry weight per $\mathrm{m}^{2}$ ) at several crayfish (Procambarus clarkii) densities $(0,1,3,5)$ in enclosures and from field samples outside the enclosures (F). Field $\mathrm{C}$ is the control field and $\mathrm{T}$ is the treatment field. DW - dry weight. clude (Table 1): adjusted grain weight production, dry weight of macrophytes, organic content of the sediments, density of rice shoots, aerial rice biomass (dry weight) excluding grain, total dry weight of aerial parts of the vegetation, and total dry weight of the aerial parts of rice (including grain). All the values were expressed per square meter, with the exception of the organic content, which was expressed as the percentage per sample. Average values for both fields were: adjusted grain weight production-681.1 $\mathrm{g} \mathrm{m}^{-2}$, dry weight of macrophytes $5.9 \mathrm{~g} \mathrm{~m}^{-2}$, organic content of the sediments $-1.945 \%$, density of rice shoots -328.8 per $\mathrm{m}^{2}$, aerial rice biomass (dry weight) excluding grain $-459.4 \mathrm{~g} \mathrm{~m}^{-2}$, total dry weight of aerial parts of the vegetation-1051.1 g $\mathrm{m}^{-2}$, total dry weight of aerial parts of rice (including grain)-1045.2 $\mathrm{g} \mathrm{m}^{-2}$. Additional parameters calculated were: the number of filled grains per panicle, with a value of 59.4 in field $\mathrm{C}$ and 68.36 in field $\mathrm{T}$; the percentage of empty grains with a value of $12.65 \%$ in field $\mathrm{C}$ and $9.32 \%$ in field T; and the 100 grains weight, with a value of $2.536 \mathrm{~g}$ in field $\mathrm{C}$ and $2.567 \mathrm{~g}$ in field $\mathrm{T}$. No statistical comparison was possible for these last parameters.

\subsection{Impact caused by the enclosures}

A comparison of the values obtained outside and inside the enclosures, in the absence of crayfish (Table 2), showed in both fields a decrease in: the adjusted rice grain weight (Fig. 1), dry weight of macrophytes (Fig. 2), total vegetal biomass (DW), and total rice biomass (DW) (Fig. 3). There was an increase in the number of rice shoots inside the enclosures without crayfish (Fig. 4). Nevertheless, none of the differences were statistically significant $(p>0.05$ for all comparisons, Mann-Whitney U test).

\subsection{Crayfish effects on rice and infestants-samples obtained in the enclosures}

No perceptible reduction in crayfish activity was observed following the application of Genapol OX-80 in field T. An ANOVA was applied to both the treatment $(\mathrm{T})$ and control $(\mathrm{C})$ field show- 
Table 1

Results (at harvest time) of experiments in two rice fields, respectively with and without the use of a surfactant ${ }^{\mathrm{a}, \mathrm{b}, \mathrm{c}}$

\begin{tabular}{|c|c|c|c|c|c|c|c|c|c|}
\hline Field & $\begin{array}{l}\text { Crayfish } \\
\text { density }\end{array}$ & Grain DW (g) & $\begin{array}{l}\text { Adjusted grain } \\
\text { weight (g) } \\
(14 \% \text { moisture) }\end{array}$ & $\begin{array}{l}\text { Macrophytes } \\
\text { DW (g) }\end{array}$ & $\begin{array}{l}\% \text { Organic } \\
\text { content of } \\
\text { sediments }\end{array}$ & $\begin{array}{l}\text { Number of } \\
\text { rice shoots }\end{array}$ & $\begin{array}{l}\text { Rice DW } \\
\text { excluding } \\
\text { grain }(\mathrm{g})\end{array}$ & $\begin{array}{l}\text { Total DW }(\mathrm{g}) \\
\text { vegetative } \\
\text { biomass }\end{array}$ & $\begin{array}{l}\text { Total DW }(\mathrm{g}) \\
\text { rice biomass }\end{array}$ \\
\hline $\mathrm{C}$ & 0 & 518.36 & 602.74 & 4.75 & 1.29 & 409.67 & 492.02 & 1015.13 & 1010.38 \\
\hline $\mathrm{C}$ & 1 & 361.87 & 420.78 & 4.63 & 2.46 & 188.67 & 221.82 & 588.32 & 583.69 \\
\hline $\mathrm{C}$ & 3 & 0.00 & 0.00 & 1.41 & 1.58 & 0.00 & 0.00 & 1.41 & 0.00 \\
\hline $\mathrm{C}$ & 5 & 0.00 & 0.00 & 0.26 & 1.63 & 0.00 & 0.00 & 0.26 & 0.00 \\
\hline $\mathrm{C}$ & Field & 606.89 & 705.68 & 6.23 & 1.65 & 349.20 & 481.63 & 1094.76 & 1088.52 \\
\hline $\mathrm{T}$ & 0 & 517.53 & 601.78 & 8.02 & 2.58 & 399.00 & 474.53 & 1000.08 & 992.06 \\
\hline $\mathrm{T}$ & 1 & 243.11 & 282.69 & 8.83 & 2.72 & 118.67 & 209.21 & 461.15 & 452.32 \\
\hline $\mathrm{T}$ & 3 & 0.00 & 0.00 & 3.11 & 1.92 & 0.00 & 0.00 & 3.11 & 0.00 \\
\hline $\mathrm{T}$ & 5 & 0.00 & 0.00 & 0.00 & 2.56 & 0.00 & 0.00 & 0.00 & 0.00 \\
\hline $\mathrm{T}$ & Field & 564.52 & 656.42 & 5.62 & 2.24 & 308.40 & 437.25 & 1007.40 & 1001.78 \\
\hline
\end{tabular}

a Standard field samples were taken (without crayfish infestation) and enclosures were used to test several crayfish densities (0, 1 , 3 , 5).

${ }^{b}$ N.B. Only aerial biomass was considered and all the values represent the average per $\mathrm{m}^{2}$.

${ }^{\mathrm{c}} \mathrm{C}$, control field; T, treatment field with Genapol OX-80; DW, dry weight. 
Table 2

Impact of crayfish (Procambarus clarkii) and enclosures on rice production ${ }^{\mathrm{a}, \mathrm{b}}$

\begin{tabular}{|c|c|c|c|c|c|c|c|}
\hline Field & $\begin{array}{l}\text { Crayfish density } \\
\left(\mathrm{n} \mathrm{m}^{-2}\right)\end{array}$ & 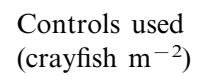 & $\begin{array}{l}\text { Adjusted grain weight } \\
(14 \% \text { moisture })\end{array}$ & $\begin{array}{l}\text { Macrophytes } \\
\text { DW }\end{array}$ & $\begin{array}{l}\text { Number of rice } \\
\text { shoots }\end{array}$ & $\begin{array}{l}\text { Total DW vegetative } \\
\text { biomass }\end{array}$ & $\begin{array}{l}\text { Total DW rice } \\
\text { biomass }\end{array}$ \\
\hline $\mathrm{C}$ & 0 & $\mathrm{~F}$ & $14.59(-)$ & $23.81(-)$ & $17.32(+)$ & $7.27(-)$ & $7.18(-)$ \\
\hline $\mathrm{C}$ & 1 & 0 & $30.19(-)$ & $2.53(-)$ & $53.95(-)$ & $42.05(-)$ & $42.23(-)$ \\
\hline $\mathrm{C}$ & 5 & 0 & $100.00(-)$ & $94.53(-)$ & $100.00(-)$ & $99.97(-)$ & $100.00(-)$ \\
\hline $\mathrm{T}$ & 0 & $\mathrm{~F}$ & $8.32(-)$ & $42.65(+)$ & $29.38(+)$ & $0.73(-)$ & $0.97(-)$ \\
\hline $\mathrm{T}$ & 1 & 0 & $53.02(-)$ & $9.17(+)$ & $70.26(-)$ & $53.89(-)$ & $54.41(-)$ \\
\hline
\end{tabular}

${ }^{a}$ N.B. All values are expressed as a percentage impact when compared with controls. + and - are positive and negative impacts, respectively.

${ }^{\mathrm{b}} \mathrm{C}$, control field; T, treatment field with Genapol OX-80; DW, dry weight; F, field samples outside the enclosures (without crayfish). 


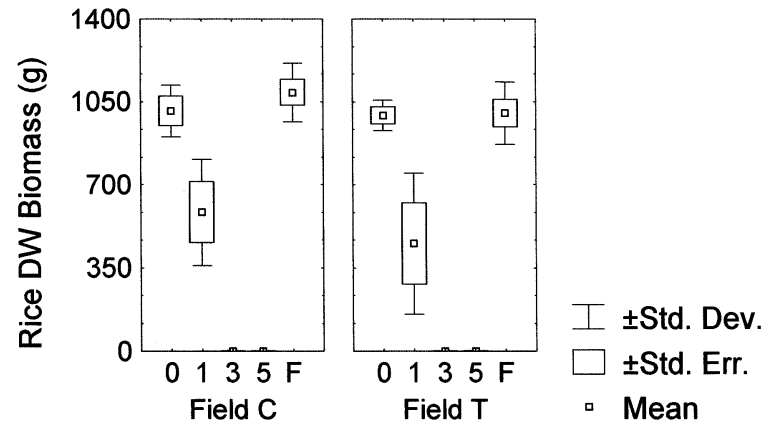

Treatments

Fig. 3. Total aerial rice biomass per $\mathrm{m}^{2}$ at several crayfish (Procambarus clarkii) densities $(0,1,3,5)$ in enclosures and from field samples outside the enclosures $(\mathrm{F})$. Field $\mathrm{C}$ is the control field and $\mathrm{T}$ is the treatment field. DW-dry weight.

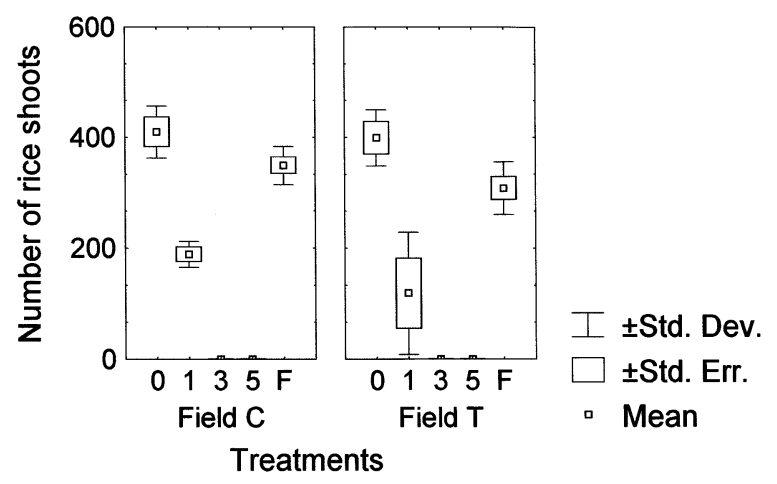

Fig. 4. Number of rice shoots per $\mathrm{m}^{2}$ at several crayfish (Procambarus clarkii) densities $(0,1,3,5)$ in enclosures and from field samples outside the enclosures $(\mathrm{F})$. Field $\mathrm{C}$ is the control field and $\mathrm{T}$ is the treatment field. DW-dry weight.

ing non significant $(p<0.05)$ results for the effects of crayfish density on the final: (a) adjusted rice grain weight production; (b) infesting macrophytes dry weight; (c) number of rice shoots and (d) total dry weight of aerial rice plant.

In both fields, there was a total destruction of rice within the enclosures with densities of 3 and 5 crayfish $\mathrm{m}^{-2}$ (Tables 1 and 2). However, some infesting macrophytes, mostly Lindernia dubia, survived at 3 crayfish $\mathrm{m}^{-2}$ in both fields (Tables 1 and 2) and at 5 crayfish $\mathrm{m}^{-2}$ in field $\mathrm{C}$ (Tables 1 and 2). Macrophyte biomass was always small when compared with rice, with average values ranging from 0 to $8.83 \mathrm{~g} \mathrm{~m}^{-2}$.
In general, the comparison of the results between enclosures with 1 crayfish $\mathrm{m}^{-2}$ and the control (no crayfish), showed a detrimental effect caused by crayfish (Table 2). The only exception was observed in field $\mathrm{T}$, where the macrophyte $\mathrm{DW}$, seemed to increase in the presence of 1 crayfish $\mathrm{m}^{-2}$. The decrease in rice grain production attributable to 1 crayfish $\mathrm{m}^{-2}$ was $30.19 \%$ in field $\mathrm{C}$ and $53.02 \%$ in field $\mathrm{C}$ and $\mathrm{T}$.

\subsection{Sediment organic matter}

Sediment organic content (Table 1) averaged $2 \%$ and was apparently not influenced by the surfactant or by crayfish density. No statistically significant correlation $(p>0.05)$ was found with the parameters cited in the previous sections and the sediment organic content.

\section{Discussion and conclusions}

Genapol OX-80 was not effective in preventing crayfish damage to rice crops nor did it affect rice production. As opposed to laboratory observations (Cabral et al., 1996; Fonseca et al., 1996) reduction of crayfish activity was not observed in the field. This might be related to the high quantity of sediments suspended in the water when the surfactant was applied. Actually, surfactants are expected to have a high affinity to surfaces, namely of suspended materials (Hem et al., 1982; Vaution, 1983). Although enough surfactant was applied to the field, it is possible that most of it was unavailable to crayfish. Moreover, adsorbed surfactant molecules may undergo degradation reactions at a faster rate (Hem et al., 1982). Recent works (Anastácio and Marques, 1996), proved that turbidity may increase due to crayfish activity. Therefore, in a situation in which a field contains a high density of crayfish, i.e. where the surfactant can be used, it will predictably be ineffective, at least in the present formulation. From a practical point of view this will result in a failure of the product. Genapol cannot be applied several times to the rice fields without an excessive economic cost. 
In experiments with confined crayfish, Grigarick and Way (1982) obtained seedling reductions ranging from $8.6 \%$ with 0.34 crayfish $\mathrm{m}^{-2}$, to $94 \%$ with 2.4 crayfish $\mathrm{m}^{-2}$. Anastácio and Marques (1996) obtained an average rice seedling reduction of $65.6 \%$ with 1 crayfish $\mathrm{m}^{-2}$. At low plant densities, the individual plant weight tends to increase (Kershaw, 1973; Etherington, 1982), following the 'reciprocal yield law' (Yoda et. al., 1963 in Kershaw, 1973), therefore, the values obtained by the previous works could not be taken as crop losses. In this work, the decrease in grain production attributable to a density of 1 crayfish $\mathrm{m}^{-2}$ was 30.19 and $53.02 \%$, respectively in fields $\mathrm{C}$ and $\mathrm{T}$. The higher impact of crayfish on the treatment field could be related to individual variation. Only six crayfish were involved in the experiments at a density of 1 crayfish $\mathrm{m}^{-2}$, and therefore an average value of $41.61 \%$ should be considered for the calibration of an ecological model. This value is considerably smaller than the previously observed reductions in seedlings in the same area (Anastácio and Marques, 1996). Nevertheless the average reduction in rice shoots in both fields was $62.11 \%$, which is very similar to the seedling reductions of $65.6 \%$ obtained in the previous work (Anastácio and Marques, 1996). Therefore a model calibration with this value would be quite consistent.

In wet seeded rice, crayfish impact is stronger at the initial phases of rice growth, i.e. the impact on final rice grain production is smaller than what is suggested by the seedling reduction observed by Anastácio and Marques (1996). It is our belief that the reduction in rice crop production due to crayfish presence is linked to the traditional method of growing rice. In the Lower Mondego River valley, rice fields are flooded before sowing, and the water level is kept as high as $10 \mathrm{~cm}$ or more. If fields were sown before flooding (3 weeks), like in southern USA (Anonymous, 1973 in Grigarick and Way, 1982), or if water levels are kept very low $(2-3 \mathrm{~cm})$ at the time of seedling emergence, most problems arising from crayfish destruction of seed and young rice plants might be avoided. This is in fact one of the scenarios being tested by models of simultaneous crayfish and rice production in the area.

\section{Acknowledgements}

This work was developed in the scope of the EU research project AIR 3CT 94-2432. The authors are indebted to António Carriço who provided the fields, and always helped. Furthermore, we want to thank the Portuguese Forestry Department and the 'Quinta do Seminário' farm staff who assisted in the preparation of the enclosures. A special thanks goes to my colleagues, João Alexandre, Rute, Claudia and Sofia, who helped in some of the toughest parts of the field work.

\section{References}

Adão, H., Marques, J.C., 1993. Population biology of the red swamp crayfish Procambarus clarkii (Girard, 1852) in southern Portugal. Crustaceana 65, 336-345.

Anastácio, P.M., Marques, J.C., 1995. Population biology and production of the red swamp crayfish Procambarus clarkii (Girard) in the Lower Mondego River valley, Portugal. J. Crustac. Biol. 15 (1), 156-168.

Anastácio, P.M., Marques, J.C., 1996. Crayfish (Procambarus clarkii) effects on initial stages of rice growth in the Lower Mondego River valley, Portugal. Freshw. Crayfish 11, $608-618$.

Anastácio, P.M., Nielsen, S.N., Marques, J.C., Jørgensen, S.E., 1995. Integrated production of crayfish and rice: a management model. Ecol. Eng. 4, 199-210.

Anastácio, P.M., Nielsen, S.N., Marques, J.C., 1999. CRISP (Crayfish and Rice Integrated System of Production): 3. Modelling crayfish (Procambarus clarkii) population dynamics, in press.

Arrignon, J.C.V., Huner, J.V., Laurent, P.J., 1990. L'ecrevisse Rouge des Marais. Maisonneuve et Larose, Paris, p. 87.

Baker, L., 1975. The toxicity of the organophosphates Guthion and Azodrin to molting and nonmolting crayfish Procambarus clarkii. Freshw. Crayfish 2, 371-378.

Bellido, L.L., 1991. Arroz. In: Cereales. Mundi-Prensa, Madrid, pp. 420-491.

Brown, R.T., Avault, J.W. Jr., 1975. Toxicity of antimycin to crayfish, Procambarus spp. Freshw. Crayfish 2, 351-370.

Cabral, J.A., Anastácio, P.M., Carvalho, R., Marques, J.C., 1996. A non harmful chemical method of red swamp crayfish (Procambarus clarkii) population control and non target organisms problematics in the Lower Mondego River valley, Portugal. Freshw. Crayfish 11, 289-292.

Caño, E., Ocete, M.E., 1994. Estimación sobre las repercursiones socio-económicas de Procambarus clarkii Girard (Decapoda, Cambaridae) en las marismas del bajo Guadalquivir. Bol. San. Veg. Plagas 20, 653-660. 
Chang, V.C., Lange, W.H., 1967. Laboratory and field evaluation of selected pesticides for control of the red crayfish in California rice fields. J. Econ. Enterp. 60, 473-477.

Correia, A.M., 1993. Situation de l'acclimatation de l'écrevisse rouge des marais Procambarus clarkii au Portugal. L'astaciculteur de France 35, 2-9.

Etherington, J.R., 1982. Plants in ecosystems. In: Etherington, J.R. (Ed.), Environment and Plant Ecology. Wiley, London, pp. 377-416.

Ferreira, F.S., 1991. O baixo mondego sem projecto e com projecto. Semente 3, 26-34.

Fonseca, J.C., Marques, J.C., Madeira, V.M.C., 1996. Oxygen uptake inhibition in Procambarus clarkii, Louisiana crayfish by biodegradable surfactants: an ecotechnological approach for population control in rice fields. Freshw. Crayfish 11, 235-242.

Gomez, K.A., 1972. Techniques for field experiments with rice, The International Rice Research Institute, Los Baños, Laguna, Philippines, p. 346.

Grigarick, A.A., Way, M.O., 1982. Role of crayfish (Decapoda: Astacidae) as pests of rice in California and their control. J. Econ. Enterp. 75, 633-636.

Hem, S.L., Feldkamp, J.R., White, J.L., 1982. Basic chemical principles related to emulsion and suspension dosage forms. In: Lachman, L., et al. (Eds.), The Theory and Practice of Industrial Pharmacy. Lea \& Febiger, Philadelphia, pp. 100-122.

Holdich, D.M., 1988. The dangers of introducing alien animals with particular reference to crayfish. Freshw. Crayfish 7, $15-30$.

Hulbert, S.H., 1984. Pseudoreplication and the design of ecological field experiments. Ecol. Monogr. 54 (2), 187-211.

Huner, J.V., 1988. Procambarus in North America and elsewhere. In: Holdich, D.M. (Ed.), Freshwater Crayfish. Biol- ogy, Management and Exploitation. Croom Helm, London, pp. 239-261.

Jørgensen, S.E., 1989. Principles of ecological modelling. In: Mitsch, W.J., et al. (Eds.), Ecological Engineering. Wiley, New York, pp. 35-56.

Jørgensen, S.E., Marques, J.C., Anastácio, P.M., 1997. Modelling the fate of detergents and pesticides in a rice field. Ecol. Model. 104, 205-213.

Kershaw, K.A., 1973. Plant population dynamics. In: Quantitative and Dynamic Plant Ecology. Edward Arnold, London, pp. 105-127.

Krebs, C.J., 1989. Ecological Methodology. Harper and Row, New York, p. 654.

Mitsch, W.J., Jørgensen, S.E., 1989. Introduction to ecological engineering. In: Mitsch, W.J., et al. (Eds.), Ecological Engineering. Wiley, New York, pp. 3-12.

Roqueplo, C., Hureaux, N.D., 1989. Ecrevisses: le point. 1 partie. Aqua Rev. 27, 31-36.

Savary, S., 1993. Rice farmers background, perception of pests and pest management actions: a case study in the Philippines. Neth. J. Plant Pathol. (Suppl. 3) 99, 181-190.

Sommer, T.R., Goldman, C.R., 1983. The crayfish Procambarus clarkii from California ricefields. Ecology, problems and potential harvest. Freshw. Crayfish 5, 418-428.

Sommer, T.R., 1984. The biological response of the crayfish Procambarus clarkii to transplantation into California ricefields. Aquaculture 41, 373-384.

Vaution, C., 1983. Les agents de surface. Classification. In: Puiseaux, F., et al. (Eds.), Agents de Surface et Emulsions (Les Sistèmes Dispersés). Lavoisier, Paris, pp. 5-21.

Velez, S.A., 1980. Problematica y prespectivas de las introduccion del cangrejo, Jornadas de estudio: Technical report, Junta de Andalucia, pp. 25-78. 